\title{
MACRONUTRIENT RATES AND MULTIFUNCTIONAL MICROORGANISMS IN A TROPICAL FLOODED RICE CROP ${ }^{1}$
}

\author{
ADRIANO STEPHAN NASCENTE ${ }^{2 *}$, MARTA CRISTINA CORSI DE FILIPPI ${ }^{2}$, ANNA CRISTINA LANNA ${ }^{2}$
}

\begin{abstract}
Tropical flooded rice production systems require a high input of fertilizers and chemical defensive. The use of plant growth-promoting rhizobacteria (PGPR), a sustainable component of this system, can increase nutrient-use efficiency and lead to significant increases in the grain yield of tropical flooded rice crop. This study aimed to determine the effect of the microorganism BRM 32110 (Bacillus thuringiensis) in combination with nitrogen $(\mathrm{N})$, phosphorus $(\mathrm{P})$ and potassium $(\mathrm{K})$ application rates on the physiological and agronomic performance of tropical flooded rice plants. Trials were performed in the 2016/2017 growing season in Formoso do Araguaia, a city in Tocantins state, Brazil. Three independent experiments (E1, E2, and E3) were performed in a randomized block design in a $4 \times 2$ factorial scheme with three replications. E1 comprised four $\mathrm{N}$ application rates $\left(0,40,80\right.$ and $\left.120 \mathrm{~kg} \mathrm{~N} \mathrm{ha}^{-1}\right)$ with and without the addition of BRM 32110, E2 comprised four $\mathrm{P}_{2} \mathrm{O}_{5}$ application rates $\left(0,40,80\right.$ and $120 \mathrm{~kg} \mathrm{P}_{2} \mathrm{O}_{5}$ ha $\left.^{-1}\right)$ with or without BRM 32110, and E3 comprised four $\mathrm{K}_{2} \mathrm{O}$ application rates $\left(0,20,40\right.$ and $60 \mathrm{~kg} \mathrm{~K}_{2} \mathrm{O}$ ha $\left.{ }^{-1}\right)$ with and without BRM 32110. In fertile soil, there were no interactions between the rhizobacterium BRM 32110 and the N, P or K application rates. BRM 32110 improved nutrient uptake and, on average, increased shoot dry matter by $8 \%$, photosynthesis rate by $14 \%$ and grain yield by $11 \%$ in the flooded rice plants. Our results suggest that the use of multifunctional microorganisms is a good strategy for improving flooded rice grain yield sustainably.
\end{abstract}

Keywords: Oryza sativa. Rhizobacteria. Bacillus sp.. Physiological and agronomic attributes. Sustainable development.

\section{DOSES DE MACRONUTRIENTES E MICROORGANISMOS MULTIFUNCIONAIS NA CULTURA DO ARROZ IRRIGADO POR INUNDAÇÃO TROPICAL}

RESUMO - Os sistemas tropicais de produção de arroz inundado requerem uma alta entrada de fertilizantes e defensivos químicos. O uso de rizobactérias promotoras de crescimento de plantas (RPCP), um componente sustentável desse sistema, pode aumentar a eficiência do uso de nutrientes e levar a aumentos significativos no rendimento de grãos das culturas tropicais de arroz inundado. Este estudo teve como objetivo determinar o efeito do microrganismo BRM 32110 (Bacillus thuringiensis) em combinação com doses aplicaas de nitrogênio $(\mathrm{N})$, fósforo $(\mathrm{P})$ e potássio $(\mathrm{K})$ no desempenho fisiológico e agronômico de plantas de arroz inundadas no ambiente tropical. Os ensaios foram realizados na safra agrícola 2016/2017 em Formoso do Araguaia, cidade no estado do Tocantins, Brasil. Três experimentos independentes (E1, E2 e E3) foram realizados em delineamento de blocos ao acaso, em esquema fatorial 4 x 2, com três repetições. E1 compreendeu quatro doses aplicadas de $\mathrm{N}(0,40,80$ e $120 \mathrm{~kg} \mathrm{~N}$ ha-1) com e sem a adição de BRM 32110, E2 compreendeu quatro doses aplicadas de $\mathrm{P}_{2} \mathrm{O}_{5}\left(0,40,80\right.$ e $120 \mathrm{~kg}$ de $\left.\mathrm{P} 2 \mathrm{O} 5 \mathrm{ha}^{-1}\right)$ com ou sem BRM 32110, e E3 compreendeu quatro taxas de aplicação de $\mathrm{K}_{2} \mathrm{O}\left(0,20,40\right.$ e $\left.60 \mathrm{~kg} \mathrm{~K}_{2} \mathrm{O} \mathrm{ha}^{-1}\right)$ com e sem BRM 32110. Em solo fértil, não houve interações entre a rizobacteria BRM 32110 e taxas aplicadas de N, P ou K. O BRM 32110 melhorou a captação de nutrientes e, em média, aumentou a matéria seca da parte aérea em $8 \%$, a taxa de fotossíntese em $14 \%$ e a produtividade de grãos em $11 \%$ nas plantas de arroz inundadas. Nossos resultados sugerem que o uso de microrganismos multifuncionais é uma boa estratégia para melhorar o rendimento de grãos de arroz inundado de forma sustentável.

Palavras-chave: Oryza sativa. Rizobacteria. Bacillus sp.. Atributos fisiológicos e agronômicos. Desenvolvimento sustentável.

\footnotetext{
${ }^{*}$ Corresponding author

${ }^{1}$ Received for publication in 01/30/2020; accepted in 07/23/2020.

${ }^{2}$ Brazilian Agricultural Research Corporation, Embrapa Arroz e Feijão, Santo Antônio de Goiás, GO, Brazil; adriano.nascente@embrapa.br - ORCID: 0000-0002-6014-3797, cristina.filippi@embrapa.br - ORCID: 0000-0003-1676-8164, anna.lanna@embrapa.br - ORCID: 00000001-8018-9349.
} 


\section{INTRODUCTION}

The production of rice, along with corn and wheat, accounts for approximately $60 \%$ of all the fertilizers used worldwide (LADHA et al., 2005; FAGERIA, 2009, 2014). However, these fertilizers are derived from petroleum and expensive, and their incorrect use can cause damage to the environment, such as the contamination of water sources (MARTINS et al., 2015). On the other hand, to meet the growing global demand for rice over the next 30 years, it is necessary to increase current production by more than 50\% (GRiSP, 2013). Therefore, the development of sustainable technologies is necessary to provide significant increases in crop grain yield to meet this growing demand (NASCENTE et al., 2017a).

Among the existing technologies for reducing the use of fertilizers in rice crops, the use of beneficial microorganisms, such as plant growthpromoting rhizobacteria (PGPR), is becoming a popular strategy for sustainable agriculture (AHEMAD; KIBRET, 2014; BARIS et al., 2014; SPERANDIO et al., 2017; NASCENTE et al., 2019a). These microorganisms can act directly and indirectly on plant development (AHEMAD; KIBRET, 2014).

The direct effects of PGPR are exemplified by the fixation of biological nitrogen (BNF); the production of hormones, such as indole-3-acetic acid (IAA), cytokines and gibberellins; the solubilization of phosphate; the production of siderophores; the activity of hydrolytic enzymes such as lipases and proteases; and the acceleration of organic matter mineralization processes (BULGARELLI et al., 2013; AHEMAD; KIBRET, 2014; OLANREWAJU; GLICK; BABALOLA, 2017). The indirect effects of PGPR are related to the pathogen-antagonist interaction with the target species or the development of plant resistance to pathogens and abiotic stressors (KUAN et al., 2016). Examples of the direct and indirect beneficial effects of PGPR on rice plant development include increases in grain yield, nutrient uptake (NASCENTE et al., 2017a, b; NASCENTE et al., 2019a, b), and rice blast suppression by parasitism of the pathogen (SPERANDIO et al., 2017). In this sense, beneficial microorganisms can be defined as multifunctional and represent sustainable alternatives for supporting the intensification of agricultural systems.

Previous studies allowed the selection and identification of beneficial rhizobacteria collected from upland rice fields (FILIPPI et al., 2011) and isolates of the fungus Trichoderma asperellum collected from rhizosphere soil in reforestation areas and native Amazon forest (SILVA et al., 2012; FRANÇA et al., 2015). Later, Nascente et al. (2017a) tested these microorganisms under greenhouse conditions and showed that rhizobacterium BRM 32114 (Serratia sp.) provided the best results for upland rice development. After this, Nascente et al. (2019a) tested this microorganism under field conditions and showed that its use led to a reduction in the application of nitrogen fertilizers to upland rice crops.

In flooded rice systems, Sousa, Nascente and Filippi (2019) showed that the use of PGPR led to significant increases in root length relative to that in a rhizobacteria-free treatment (i.e., a control). In another experiment conducted in greenhouse conditions, the effects of six PGPR on flooded rice development were evaluated, and the treatment with rhizobacterium BRM 32110 (Bacillus sp.) stood out (NASCENTE et al., 2017b). This microorganism is characterized as a producer of cellulase, phosphatase, siderophores and biofilm (NASCENTE et al., 2017a). Therefore, BRM 32110 was selected for testing under field conditions. This study aimed to determine the effects of BRM 32110 in combination with nitrogen $(\mathrm{N})$, phosphorus $(\mathrm{P})$ and potassium $(\mathrm{K})$ at various application rates on the physiological and agronomic performances of tropical flooded rice plants under field conditions.

\section{MATERIAL AND METHODS}

\section{Site description}

The experiments were conducted at Unitins Experimental Station ( $11^{\circ} 47^{\prime} 48^{\prime \prime} \mathrm{S}$ and $49^{\circ} 31^{\prime} 44^{\prime \prime}$ W), located in Formoso do Araguaia city, state of Tocantins, Brazil. The study site is at an elevation of $240 \mathrm{~m}$. According to the Köppen classification, the climate is tropical savanna (ALVARES et al., 2014). There are two well-defined seasons: a usually dry season from May to September (autumn/winter) and a wet season from October to April (spring/summer). The average annual rainfall is $1,719 \mathrm{~mm}$, and the average annual temperature is $26.7^{\circ} \mathrm{C}$.

The soil in the experimental plots was Inceptisol according to the US soil classification system and Gley humic according to the Brazilian soil classification system. Prior to the study, in October 2016, chemical and physical analyses were performed according to the methods described by Donagema et al. (2011) for the initial characterization of the area. The initial soil chemical properties at the experimental site in the 0 to $20 \mathrm{~cm}$ soil layer were was follows: $\mathrm{pH}, 5.4$; soil organic matter (SOM), $24.05 \mathrm{~g} \mathrm{~kg}^{-1}$; $\mathrm{P}, 20.9 \mathrm{mg} \mathrm{kg}{ }^{-1}$; K, 133 $\mathrm{mg} \mathrm{kg}{ }^{-1}$; Ca, $2.95 \mathrm{cmol}_{\mathrm{c}} \mathrm{kg}^{-1} ; \mathrm{Mg}, 1.16 \mathrm{cmol}_{\mathrm{c}} \mathrm{kg}^{-1}$; $\mathrm{Al}, 0.1 \mathrm{cmol}_{\mathrm{c}} \mathrm{kg}^{-1} ; \mathrm{Cu}, 2.6 \mathrm{mg} \mathrm{kg}{ }^{-1} ; \mathrm{Zn}, 3.3 \mathrm{mg} \mathrm{kg}^{-1}$; $\mathrm{Fe}, 220 \mathrm{mg} \mathrm{kg}^{-1}$; and $\mathrm{Mn}, 34.9 \mathrm{mg} \mathrm{kg}^{-1}$. A textural analysis of this site revealed that the soil was composed of $303 \mathrm{~g}$ clay kg $^{-1}, 140 \mathrm{~g}$ silt kg $\mathrm{kg}^{-1}$, and 557 $\mathrm{g}$ sand $\mathrm{kg}^{-1}$. The soil $\mathrm{pH}$ was measured in a $1: 2.5$ soil:water suspension. $\mathrm{P}$ and $\mathrm{K}$ were extracted by Mehlich 1 extracting solution $(0.05 \mathrm{M} \mathrm{HC1}$ in $\left.0.0125 \mathrm{M} \mathrm{H}_{2} \mathrm{SO}_{4}\right)$. From the extracts, the $\mathrm{P}$ content 
was determined colorimetrically, and $\mathrm{K}$ was determined by flame photometry. $\mathrm{Ca}, \mathrm{Mg}$, and $\mathrm{Al}$ were extracted with $1 \mathrm{M} \mathrm{KC1}$. The $\mathrm{Al}$ content was determined by titration with $\mathrm{NaOH}$, and the $\mathrm{Ca}$ and $\mathrm{Mg}$ contents were determined by titration with EDTA. The micronutrient content was determined from the portion of the extract used to quantify the $\mathrm{P}$ content by atomic absorption spectrophotometry. The soil organic matter content was determined by Walkley \& Black's method.

\section{Experimental design and treatments}

Three independent experiments were performed, one for each nutrient $(\mathrm{N}, \mathrm{P}$ and $\mathrm{K})$. The trials were arranged in randomized complete blocks in a $4 \times 2$ factorial scheme, with four replications during only one growing season $(2016 / 17)$. The plots had dimensions of $3.9 \mathrm{~m} \times 6 \mathrm{~m}$, and 12 rows of rice constituted the usable area, disregarding $0.50 \mathrm{~m}$ on each side of the rows in each plot. For all three experiments, the treatments were as follows: 1. Four doses of $\mathrm{N}\left(0,40,80\right.$ and $\left.120 \mathrm{~kg} \mathrm{ha}^{-1}\right)$; 2. four doses of $\mathrm{P}\left(0,40,80\right.$ and $\left.120 \mathrm{~kg} \mathrm{P}_{2} \mathrm{O}_{5} \mathrm{ha}^{-1}\right)$; and 3. four doses of $\mathrm{K}_{2} \mathrm{O}\left(0,20,40\right.$ and $\left.60 \mathrm{~kg} \mathrm{ha}^{-1}\right)$. All three experiments were tested with and without BRM 32110 (Bacillus thuringiensis). Bacillus thuringiensis strain BRM32110 belongs to the Microorganism Culture Collection at the Embrapa Rice and Bean Research Center (GenBank accession code KX378746).

Seed microbiolization and pulverization of the BRM 32110 suspension for the soil and plant

For the microbiolization process, BRM 32110 was first cultivated for 24 hours on solid medium 523 (KADO; HESKETT, 1970) at $28{ }^{\circ} \mathrm{C}$. For the preparation of the suspension, bacterial cells were harvested with water, and the concentration was set with a spectrophotometer (A540 $=0.5,10^{8}$ UFC). Rice seeds were immersed in the bacterial suspension for 24 hours under constant agitation at $25{ }^{\circ} \mathrm{C}$, and control seeds (bacteria-free) were immersed in water for 24 hours at $25^{\circ} \mathrm{C}$, according to Sperandio et al. (2017). Plant and soil pulverization was performed at 7 and 15 days after sowing. The BRM 32110 suspension was prepared as described above (at the same concentration $\left(10^{8}\right.$ UFC)) and delivered at $6001 \mathrm{ha}^{-1}$ with a costal atomizer, according to Filippi et al. (2011).

\section{Rice crop management}

Flooded rice, cultivar BRS Catiana, was mechanically sowed with a row spacing of $17 \mathrm{~cm}$ and 100 seeds per metre. $\mathrm{N}$ fertilizer was applied at a rate of $100 \mathrm{~kg} \mathrm{ha}^{-1}$; half of the $\mathrm{N}$ was applied at sowing and the remaining half as topdressing during the active tillering growth stage in the $\mathrm{P}$ and $\mathrm{K}$ trials.
At the time of sowing, $60 \mathrm{~kg} \mathrm{P}_{2} \mathrm{O}_{5} \mathrm{ha}^{-1}$ and $60 \mathrm{~kg}$ $\mathrm{K}_{2} \mathrm{O}$ ha $^{-1}$ were also applied in the $\mathrm{N}$ and $\mathrm{K}$ trials and the $\mathrm{N}$ and $\mathrm{P}$ trials, respectively. The $\mathrm{N}$ source was urea $\left(\mathrm{CH}_{4} \mathrm{~N}_{2} \mathrm{O}\right)$, the $\mathrm{P}$ source was triple superphosphate, and the $\mathrm{K}$ source was potassium chloride. In addition, in all three trials, the N, P and $\mathrm{K}$ application rates varied by treatment. Rice sowing in all the trials was performed on November $8^{\text {th }}$, 2016. On average, rice plant emergence occurred four days after sowing. The area was irrigated by subirrigation, and the soil was kept saturated. Cultural practices were performed according to standard rice crop recommendations, keeping crops free from weeds, diseases, and insects. Rice harvesting was performed on March 14 ${ }^{\text {th }}, 2017$.

\section{Agronomic and physiological parameters}

Gas exchange - A portable gas exchange analyser in the infrared region (LCpro, ADC BioScientific, Hoddesdon, England) was used to measure gas exchange. Three upland rice plants in the vegetative and reproductive stages per plot were randomly selected for use in the gas exchange measurements. The photosynthetic rate $(A, \mu \mathrm{mol}$

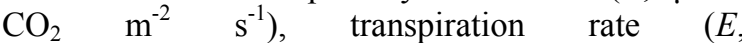
mmol $\mathrm{H}_{2} \mathrm{O} \mathrm{m}^{-2} \mathrm{~s}^{-1}$ ), stomatal conductance ( $g S$, mol $\left.\mathrm{H}_{2} \mathrm{O} \mathrm{m}^{-2} \mathrm{~s}^{-1}\right)$, internal $\mathrm{CO}_{2}$ concentration $(\mathrm{Ci}$, vpm) and leaf temperature (Tleaf, $\left.{ }^{\circ} \mathrm{C}\right)$ were obtained. Because the evaluation of gas exchange performance is best done during the highest photosynthetic photon flux density (PPFD) and before air temperatures reach limiting values for $\mathrm{C} 3$ plants (FEISTLER; HABERMANN, 2012), the readings were taken from 08:00 to 10:00 AM at 37 (vegetative stage) and 68 (reproductive stage) DAS. The samples were taken in the middle third of the first fully expanded leaf (top to base) during the first evaluation and on the flag leaf during the second evaluation. The equipment was set to use concentrations of 370-400 mol mol ${ }^{-1} \mathrm{CO}_{2}$ in the air, which is the reference condition used in the IRGA photosynthesis chamber. The PPFD used was $1200 \mu \mathrm{mol}$ [quanta] $\mathrm{m}^{-2} \mathrm{~s}^{-1}$. The minimum equilibration time for performing the reading was 2 minutes.

Nutrient content - A total of 50 flag leaves per plot were selected randomly during the full blooming stage. The leaves were washed, dried under forced air circulation at $65{ }^{\circ} \mathrm{C}$ for $72 \mathrm{~h}$ and ground. The concentrations of $\mathrm{N}, \mathrm{P}, \mathrm{K}, \mathrm{Ca}, \mathrm{Mg}, \mathrm{Cu}$, $\mathrm{Zn}, \mathrm{Fe}$, and $\mathrm{Mn}$ were determined using methods described by Donagema et al. (2011).

Shoot dry matter - One-meter long shoots from one of the rows in each plot were sampled during the full blooming stage. The shoots were washed in water, dried in an oven with forced air circulation at $65^{\circ} \mathrm{C}$ for $72 \mathrm{~h}$ and then weighed.

Grain yield and yield components - The harvest was carried out by hand after the grains in the usable area of each plot reached physiological 
maturity (March $14^{\text {th }}, 2017$ ). The number of panicles per metre was determined by counting the number of panicles in a $1.0 \mathrm{~m}$ row within the useful area of each plot. The number of grains per panicle was determined by counting the number of grains on a sample of 10 panicles randomly collected within the useful area of each plot and dividing that number by 10. The mass was determined from the weight of 1000 randomly collected grains, and the moisture content of the grains was corrected to $13 \%$. Grain yield was determined by weighing the samples harvested from each plot, and the moisture content of the grains was corrected to $13 \%$ and converted to $\mathrm{kg} \mathrm{ha}^{-1}$.

Statistical analysis - SAS Statistical Software, SAS Institute, Cary, NC, USA, was used to perform the statistical analyses. For the three trials, i.e., the N, $\mathrm{P}$ and $\mathrm{K}$ experiments, the data for the qualitative factor (i.e., the presence or absence of BRM 32110) were subjected to an analysis of variance, and when the $\mathrm{F}$ test proved significant, the data were compared by a Tukey test at $p<0.05$. For the quantitative factors (i.e., the $\mathrm{N}, \mathrm{P}$ and $\mathrm{K}$ application rates), the results were submitted to regression analysis when $\mathrm{p}<0.05$. The blocks and all block interactions were considered random effects. The N, P and $\mathrm{K}$ application rates and the use of rhizobacteria (BRM 32110) were considered fixed effects.

\section{RESULTS AND DISCUSSION}

In both the vegetative and reproductive stages, the gas exchange efficiency was higher in the flooded rice plants treated with BRM 32110 than in the untreated plants in the $\mathrm{N}, \mathrm{P}$ and $\mathrm{K}$ trials (Tables 1 and 2). In particular, compared to the untreated tropical flooded rice plants, in the BRM 32110treated rice, the photosynthetic rate $(A)$ increased by an average of $\sim 14 \%$ and stomatal conductance $(g s)$ increased by an average of $\sim 22 \%$. According to Makino (2011) and Ono et al. (2013), photosynthetic rate and stomatal conductance have significant effects on plant growth since they have a high correlation with the initial biomass production process, potential productivity and grain yield. These findings showed that the use of this microorganism (BRM 32110) led to the same gas exchange results in a greenhouse assay by Nascente et al. (2017b) and under field conditions.

Table 1. Photosynthesis (A), transpiration (E), stomatal conductance (gs), internal $\mathrm{CO}_{2}$ concentration (Ci) and leaf temperature (Tleaf) of flooded rice plants, cultivar BRS Catiana, in the vegetative stage. The plants were treated with BRM 32110 (Bacillus thuringiensis) and different doses of nitrogen $(\mathrm{N})$, phosphorus $(\mathrm{P})$ or potassium (K). Formoso do Araguaia, growing season 2016/17.

\begin{tabular}{|c|c|c|c|c|c|}
\hline & \multicolumn{5}{|c|}{$\mathrm{N}$} \\
\hline Rhizobacterium BRM 32110 & $\mathrm{~A}$ & $\mathrm{E}$ & gs & $\mathrm{Ci}$ & Tleaf \\
\hline & $\mu \mathrm{mol} \mathrm{CO} 2 \mathrm{~m}^{-2} \mathrm{~s}^{-1}$ & $\mathrm{mmol} \mathrm{H}_{2} \mathrm{O} \mathrm{m}^{-2} \mathrm{~s}^{-1}$ & $\mathrm{~mol} \mathrm{H}_{2} \mathrm{O} \mathrm{m}^{-2} \mathrm{~s}^{-1}$ & vpm & ${ }^{\circ} \mathrm{C}$ \\
\hline Present & $33.08 \mathrm{a}$ & $9.29 \mathrm{a}$ & $3.49 \mathrm{a}$ & $343 \mathrm{a}$ & $29.9 \mathrm{a}$ \\
\hline Absent & $28.40 \mathrm{~b}$ & $8.12 \mathrm{~b}$ & $2.59 \mathrm{~b}$ & $352 \mathrm{a}$ & $29.4 \mathrm{a}$ \\
\hline Factor & \multicolumn{5}{|c|}{ ANOVA - F probability } \\
\hline $\mathrm{N}$ application rate $(\mathrm{N})$ & 0.7759 & 0.0501 & 0.5313 & 0.0552 & 0.0547 \\
\hline Rhizobacterium (R) & $<0.001$ & 0.0046 & 0.0176 & 0.1022 & 0.0797 \\
\hline \multirow[t]{2}{*}{$\mathrm{R} \times \mathrm{N}$} & 0.1178 & 0.0594 & 0.4970 & 0.0581 & 0.0523 \\
\hline & \multicolumn{5}{|c|}{$\mathrm{P}$} \\
\hline Present & $28.01 \mathrm{a}$ & $9.98 \mathrm{a}$ & $2.99 \mathrm{a}$ & $345 \mathrm{a}$ & $30.0 \mathrm{a}$ \\
\hline Absent & $26.62 \mathrm{~b}$ & $8.16 \mathrm{~b}$ & $2.57 \mathrm{~b}$ & $351 \mathrm{a}$ & $29.8 \mathrm{a}$ \\
\hline Factor & \multicolumn{5}{|c|}{ ANOVA - F probability } \\
\hline $\mathrm{P}$ application rate $(\mathrm{P})$ & 0.0541 & 0.0679 & 0.0973 & 0.0519 & 0.0577 \\
\hline Rhizobacterium (R) & 0.0465 & $<0.001$ & 0.0477 & 0.4592 & 0.4809 \\
\hline \multirow[t]{2}{*}{$\mathrm{R} \times \mathrm{P}$} & 0.0515 & 0.0503 & 0.0666 & 0.9611 & 0.9760 \\
\hline & \multicolumn{5}{|c|}{$\mathrm{K}$} \\
\hline Present & $32.13 \mathrm{a}$ & $8.93 \mathrm{a}$ & $3.40 \mathrm{a}$ & $357 \mathrm{a}$ & $30.37 \mathrm{a}$ \\
\hline Absent & $26.85 \mathrm{~b}$ & $8.92 \mathrm{a}$ & $2.94 \mathrm{~b}$ & $360 \mathrm{a}$ & $29.0 \mathrm{a}$ \\
\hline Factor & \multicolumn{5}{|c|}{ ANOVA - F probability } \\
\hline $\mathrm{K}$ application rate $(\mathrm{K})$ & 0.0367 & 0.1339 & 0.8971 & 0.3340 & 0.6711 \\
\hline Rhizobacterium (R) & $<0.0001$ & 0.9818 & 0.0496 & 0.8197 & 0.0894 \\
\hline $\mathrm{R} \times \mathrm{K}$ & 0.0701 & 0.0778 & 0.0668 & 0.4909 & 0.0940 \\
\hline
\end{tabular}

*Values followed by the same letter in each column do not differ from each other according to a Tukey test at $p<0.05$. Each mean is the average of 16 means (four replications and four N, P or K application rates).

Regarding shoot nutrient contents in the flooded rice plants, the interactions between the $\mathrm{N}$ application rate and BRM 32110 influenced $\mathrm{P}, \mathrm{K}$ and $\mathrm{Ca}$ (Table 3). Plants treated with BRM 32110 showed greater $\mathrm{P}$ and $\mathrm{Ca}$ accumulation in the shoot as the $\mathrm{N}$ application rate increased, while the $\mathrm{K}$ shoot contents remained constant with increasing $\mathrm{N}$ application rates (Figure 1). On the other hand, the untreated plants showed a reduction in the $\mathrm{P}, \mathrm{K}$ and $\mathrm{Ca}$ contents as the $\mathrm{N}$ rate increased. 
Table 2. Photosynthesis (A), transpiration (E), stomatal conductance (gs), internal $\mathrm{CO}_{2}$ concentration (Ci) and leaf temperature (Tleaf) of flooded rice plants, cultivar BRS Catiana, in the reproductive stage. The plants were treated with BRM 32110 (Bacillus thuringiensis) and different doses of nitrogen $(\mathrm{N})$, phosphorus $(\mathrm{P})$ or potassium $(\mathrm{K})$. Formoso do Araguaia, growing season 2016/17.

\begin{tabular}{|c|c|c|c|c|c|}
\hline & & & $\mathrm{N}$ & & \\
\hline Rhizobacterium BRM 32110 & A & $\mathrm{E}$ & gs & $\mathrm{Ci}$ & Tleaf \\
\hline & $\mu \mathrm{mol} \mathrm{CO} \mathrm{m}^{-2} \mathrm{~s}^{-1}$ & $\mathrm{mmol} \mathrm{H}_{2} \mathrm{O} \mathrm{m}^{-2} \mathrm{~s}^{-1}$ & $\mathrm{~mol} \mathrm{H}_{2} \mathrm{O} \mathrm{m}^{-2} \mathrm{~s}^{-1}$ & vpm & ${ }^{\circ} \mathrm{C}$ \\
\hline Present & $24.56 \mathrm{a}$ & $5.69 \mathrm{a}$ & $2.60 \mathrm{a}$ & 319 a & $30.4 \mathrm{a}$ \\
\hline Absent & $22.91 \mathrm{~b}$ & $5.68 \mathrm{a}$ & $2.71 \mathrm{a}$ & 329 a & $30.8 \mathrm{a}$ \\
\hline Factor & \multicolumn{5}{|c|}{ ANOVA $-\mathrm{F}$ probability } \\
\hline $\mathrm{N}$ application rate & 0.0993 & 0.0805 & 0.4903 & 0.0871 & 0.0551 \\
\hline Rhizobacterium (R) & 0.0203 & 0.9599 & 0.7194 & 0.0591 & 0.2454 \\
\hline $\mathrm{R} \times \mathrm{N}$ & 0.0654 & 0.0615 & 0.0529 & 0.0601 & 0.0628 \\
\hline & \multicolumn{5}{|c|}{$\mathrm{P}$} \\
\hline Present & $24.69 \mathrm{a}$ & $6.31 \mathrm{a}$ & $2.43 \mathrm{a}$ & $324 \mathrm{a}$ & $30.4 \mathrm{a}$ \\
\hline Absent & $23.05 \mathrm{~b}$ & $6.42 \mathrm{a}$ & $2.05 \mathrm{~b}$ & $323 \mathrm{a}$ & $30.2 \mathrm{a}$ \\
\hline Factor & \multicolumn{5}{|c|}{ ANOVA $-\mathrm{F}$ probability } \\
\hline $\mathrm{P}$ application rate & 0.0503 & 0.0534 & 0.1050 & 0.0611 & 0.8542 \\
\hline Rhizobacterium (R) & 0.0017 & 0.4940 & 0.0182 & 0.7274 & 0.1123 \\
\hline $\mathrm{R} \times \mathrm{P}$ & 0.0523 & 0.4198 & 0.1191 & 0.0665 & 0.0979 \\
\hline & \multicolumn{5}{|c|}{$\mathrm{K}$} \\
\hline Present & $24.25 \mathrm{a}$ & $6.17 \mathrm{a}$ & $2.89 \mathrm{a}$ & $340 \mathrm{a}$ & $29.7 \mathrm{a}$ \\
\hline Absent & $24.93 \mathrm{a}$ & $5.94 \mathrm{a}$ & $3.06 \mathrm{a}$ & $336 \mathrm{a}$ & $29.9 \mathrm{a}$ \\
\hline Factor & \multicolumn{5}{|c|}{ ANOVA $-\mathrm{F}$ probability } \\
\hline $\mathrm{K}$ application rate & 0.0602 & 0.0825 & 0.8693 & 0.0507 & 0.0533 \\
\hline Rhizobacterium (R) & 0.1528 & 0.3027 & 0.6684 & 0.1502 & 0.4170 \\
\hline $\mathrm{R} \times \mathrm{K}$ & 0.0562 & 0.0449 & 0.0691 & 0.0644 & 0.0502 \\
\hline
\end{tabular}

*Values followed by the same letter in each column do not differ from each other according to a Tukey test at $\mathrm{p}<0.05$. Each mean is the average of 16 means (four replications and four $\mathrm{N}, \mathrm{P}$ or $\mathrm{K}$ application rates).

There was no effect of $\mathrm{P}$ application rates and BRM 32110 on the shoot nutrient content of the flooded rice plants (Table 3 ). On the other hand, in the $\mathrm{K}$ trial, effects of BRM 32110 on shoots were observed for only $\mathrm{Mg}, \mathrm{Mn}$ and $\mathrm{Zn}$ contents. The increase in nutrient uptake following the use of PGPR in rice plants could be because of improvements in root development. More developed root systems can reach deeper soil layers and uptake more nutrients, as observed in our trial. Corroborating this information, Sousa, Nascente and Filippi (2019) showed that the application of PGPR BRM 32110 led to increases in root length in the flooded rice cultivar BRS Catiana and that the change in the roots of the treated plants differed from that of the control (no microorganism). According to Mantelin and Touraine (2004), the inoculation of PGPR can increase plant uptake of several nutrients, such as $\mathrm{Ca}, \mathrm{K}, \mathrm{Fe}, \mathrm{Cu}, \mathrm{Mn}$, and $\mathrm{Zn}$. This uptake usually occurs during acidification of the soil rhizosphere via organic acid production or stimulation of proton pump ATPase. Nevertheless, lower soil $\mathrm{pH}$ improves the solubilization of these nutrients. In addition, Rêgo et al. (2014) showed that rice plants treated with microorganisms have larger root systems, which can therefore uptake more nutrients than the root systems of untreated plants. Pérez-García, Romero and Vicente (2011) and Zhang et al. (2011) found that increasing root length and volume can promote a higher rate of absorption of water and minerals. Based on the results of all these authors, we can infer that in our trials, the application of BRM 32110 led to increases in lowland plant root systems, which then allowed the uptake of more nutrients.

The BRM 32110 treated rice plants showed increases of 7, 6.7 and 10\% in SDM (shoot dry matter) and 9, 15 and $8 \%$ in GY (grain yield) in the $\mathrm{N}, \mathrm{P}$ and $\mathrm{K}$ experiments, respectively (Table 4). In the $\mathrm{N}$ and $\mathrm{P}$ experiments, increases of 18 and $13 \%$ in NGP (number of grains per panicle), respectively, were observed. Moreover, in the $\mathrm{K}$ experiment, an increase of $6 \%$ was observed in the $1000 \mathrm{M}$ (mass of 1000 grains). The highest increases in the grain yield and yield components of the rice plants treated with BRM 32110 can be explained, at least in part, by the increases in gas exchange, nutrient contents and biomass production of the shoots. In other words, this microorganism positively influenced plant development. This could be because BRM 32110 is characterized as a producer of cellulase, phosphatase, siderophores, biofilm, and hormones that allowed improved root development and nutrient uptake, leading to a direct effect on biomass production (NASCENTE et al., 2017a). Therefore, this microorganism can be used in field conditions to support better plant development without the use of synthetic products. 
Table 3. Shoot macro- and micronutrient content of flooded rice, cultivar BRS Catiana, treated with BRM 32110 (Bacillus thuringiensis) and different doses of nitrogen $(\mathrm{N})$, phosphorus $(\mathrm{P})$ or potassium $(\mathrm{K})$. Formoso do Araguaia, growing season 2016/17.

\begin{tabular}{|c|c|c|c|c|c|c|c|c|c|c|}
\hline \multirow[b]{2}{*}{ Rhizobacterium BRM 32110} & \multicolumn{10}{|c|}{$\mathrm{N}$} \\
\hline & $\mathrm{N}$ & $\mathrm{P}$ & $\mathrm{K}$ & $\mathrm{Ca}$ & $\mathrm{Mg}$ & $\mathrm{S}$ & $\mathrm{Cu}$ & $\mathrm{Fe}$ & $\mathrm{Mn}$ & $\mathrm{Zn}$ \\
\hline & \multicolumn{6}{|c|}{ 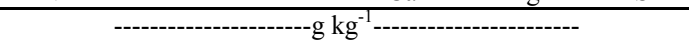 } & \multicolumn{4}{|c|}{ 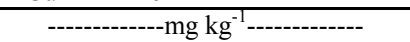 } \\
\hline Present & $31.29 \mathrm{a}$ & $3.23 \mathrm{a}$ & $16.11 \mathrm{a}$ & $6.95 \mathrm{a}$ & $2.03 \mathrm{~b}$ & $3.16 \mathrm{a}$ & $7.55 \mathrm{a}$ & $168 \mathrm{a}$ & $731 \mathrm{a}$ & $24.86 \mathrm{~b}$ \\
\hline Absent & $31.95 \mathrm{a}$ & $3.11 \mathrm{~b}$ & $16.30 \mathrm{a}$ & $6.52 \mathrm{a}$ & $2.16 \mathrm{a}$ & $3.12 \mathrm{a}$ & $8.35 \mathrm{a}$ & $205 \mathrm{a}$ & $892 \mathrm{a}$ & $27.04 \mathrm{a}$ \\
\hline Factor & \multicolumn{10}{|c|}{ ANOVA - F probability } \\
\hline Nitrogen application rate $(\mathrm{N})$ & 0.4723 & 0.2199 & 0.0029 & 0.3070 & 0.6753 & 0.3338 & 0.6686 & 0.6671 & 0.6332 & 0.2007 \\
\hline Rhizobacterium (R) & 0.1842 & 0.0432 & 0.3449 & 0.0983 & 0.0014 & 0.8465 & 0.2993 & 0.4338 & 0.0835 & 0.0191 \\
\hline \multirow[t]{2}{*}{$\mathrm{N} \times \mathrm{R}$} & 0.0885 & 0.0030 & 0.0436 & 0.0100 & 0.2466 & 0.4137 & 0.4444 & 0.4194 & 0.8752 & 0.7350 \\
\hline & & & & & $\mathrm{P}$ & & & & & \\
\hline Present & $32.24 \mathrm{a}$ & $3.09 \mathrm{a}$ & $16.75 \mathrm{a}$ & $7.18 \mathrm{a}$ & $2.41 \mathrm{a}$ & $2.58 \mathrm{a}$ & $7.64 \mathrm{a}$ & $134 \mathrm{a}$ & $1200 \mathrm{a}$ & $23.42 \mathrm{a}$ \\
\hline Absent & $31.62 \mathrm{a}$ & $3.02 \mathrm{a}$ & $16.81 \mathrm{a}$ & $6.83 \mathrm{a}$ & $2.36 \mathrm{a}$ & $2.78 \mathrm{a}$ & $7.83 \mathrm{a}$ & $138 \mathrm{a}$ & $1234 \mathrm{a}$ & $23.48 \mathrm{a}$ \\
\hline Factor & \multicolumn{10}{|c|}{ ANOVA - F probability } \\
\hline Phosphorus application rate $(\mathrm{P})$ & 0.5514 & 0.6658 & 0.0562 & 0.6513 & 0.8125 & 0.5361 & 0.5143 & 0.8672 & 0.7724 & 0.8177 \\
\hline Rhizobacterium (R) & 0.4725 & 0.1586 & 0.7998 & 0.1165 & 0.4208 & 0.2181 & 0.5790 & 0.5851 & 0.4941 & 0.8785 \\
\hline \multirow[t]{2}{*}{$\mathrm{P} \times \mathrm{R}$} & 0.1423 & 0.6223 & 0.5171 & 0.0556 & 0.4589 & 0.4572 & 0.3442 & 0.3368 & 0.1559 & 0.3527 \\
\hline & \multicolumn{10}{|c|}{$\mathrm{K}$} \\
\hline Present & $27.47 \mathrm{a}$ & $3.00 \mathrm{a}$ & $20.60 \mathrm{a}$ & $6.71 \mathrm{a}$ & $2.70 \mathrm{a}$ & $2.59 \mathrm{~b}$ & $7.73 \mathrm{a}$ & $120 \mathrm{a}$ & $849 \mathrm{a}$ & $23.31 \mathrm{~b}$ \\
\hline Absent & $26.75 \mathrm{a}$ & $3.09 \mathrm{a}$ & $20.02 \mathrm{a}$ & $6.92 \mathrm{a}$ & $2.59 \mathrm{~b}$ & $2.98 \mathrm{a}$ & $7.55 \mathrm{a}$ & $106 \mathrm{a}$ & $752 \mathrm{~b}$ & $24.83 \mathrm{a}$ \\
\hline Factor & \multicolumn{10}{|c|}{ ANOVA - F probability } \\
\hline Potassium application rate $(\mathrm{K})$ & 0.2445 & 0.8697 & 0.7676 & 0.6896 & 0.3500 & 0.8620 & 0.7893 & 0.5492 & 0.5540 & 0.6147 \\
\hline Rhizobacterium (R) & 0.1526 & 0.0575 & 0.7365 & 0.4640 & 0.0110 & 0.0081 & 0.6629 & 0.3804 & 0.0017 & 0.0018 \\
\hline $\mathrm{K} \times \mathrm{R}$ & 0.3713 & 0.1259 & 0.1960 & 0.4386 & 0.4594 & 0.4227 & 0.9397 & 0.7049 & 0.7854 & 0.6354 \\
\hline
\end{tabular}

*Values followed by the same letter in each column do not differ from each other according to a Tukey test at $\mathrm{p}<0.05$. Each mean is the average of 16 means (four replications and four N, P or K application rates).

In the $\mathrm{N}$ trial, there was a single effect of BRM 32110 on SDM, NGP and GY, and there was a single effect of $\mathrm{N}$ application rate on SDM, NGP, $1000 \mathrm{M}$ and GY (Figure 2). According to Fageria
(2014), nitrogen is a nutrient that is a component of many structural parts of plants, and increasing its values normally increases the biomass, yield components and grain yield of plants.
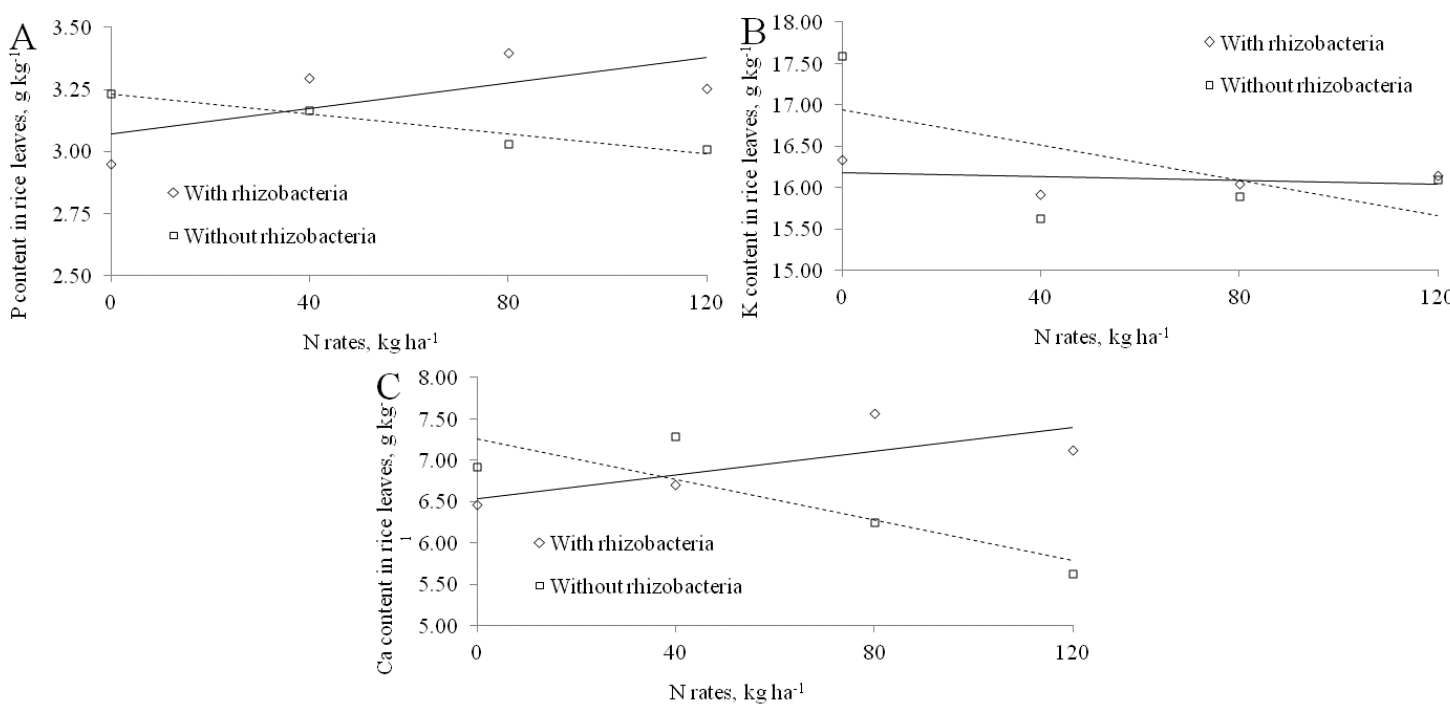

Figure 1. Shoot $\mathrm{P}, \mathrm{K}$ and $\mathrm{Ca}$ contents (A, B and C, respectively) in tropical flooded rice with and without rhizobacterium BRM 32110 as a function of N application rates. Formoso do Araguaia, growing season 2016/2017. 


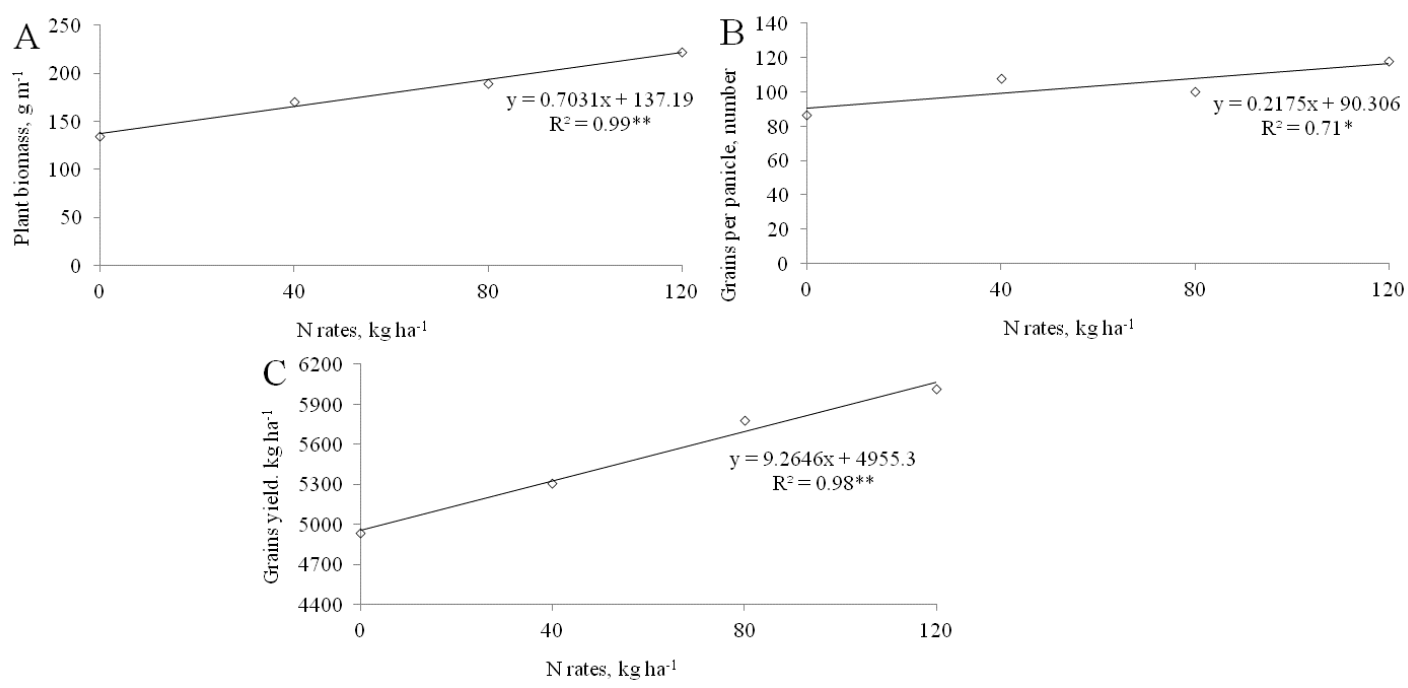

Figure 2. Plant biomass (A), number of grains per panicle (B) and grain yield (C) of tropical flooded rice as affected by $\mathrm{N}$ rates. Formoso do Araguaia, growing season 2016/2017.

In the $\mathrm{P}$ trial, there was no effect of $\mathrm{P}$ application rate on SDM, NPP, NGP, $1000 \mathrm{M}$ or GY, which means that the same GY was observed regardless of the increase in $P$. However, there was a single effect of BRM 32110 on SDM, NGP, 1000 M and GY. The lack of an effect from the $\mathrm{P}$ application rate suggests that (a) the amount of $\mathrm{P}$ in the experimental soil prior to planting was already sufficient for the growth and development of the flooded rice plants $\left(20.9 \mathrm{mg} \mathrm{kg}^{-1}\right.$; SOUSA;
LOBATO, 2004) and/or (b) the presence of BRM 32110 promoted the mineralization of nonlabile soil $\mathrm{P}$, making this nutrient available for plant uptake and leading to the same GY at $0,40,80$ and $120 \mathrm{~kg} \quad \mathrm{P}_{2} \mathrm{O}_{5} \mathrm{ha}^{-1}$. BRM 32110 can solubilize phosphorus (NASCENTE et al., 2017a) by secreting organic acids and enzymes that act on insoluble phosphates, transforming them into soluble forms (FILIPPI et al., 2011; LAVAKUSH et al., 2014).

Table 4. Shoot dry matter (SDM), number of panicles per plant (NPP), number of grains per panicle (NGP), 1000 grain mass $(1000 \mathrm{M})$ and grain yield (GY) of flooded rice, cultivar BRS Catiana, treated with BRM 32110 (Bacillus thuringiensis) and different doses of nitrogen $(\mathrm{N})$, phosphorus $(\mathrm{P})$ or potassium $(\mathrm{K})$. Formoso do Araguais, growing season 2016/17.

\begin{tabular}{|c|c|c|c|c|c|}
\hline \multirow[b]{2}{*}{ Rhizobacterium BRM 32110} & \multicolumn{5}{|c|}{$\mathrm{N}$} \\
\hline & SDM & NPP & NGP & $1000 \mathrm{M}$ & GY \\
\hline & $\mathrm{g} \mathrm{m}^{-2}$ & unit & unit & $\mathrm{g}$ & $\mathrm{kg} \mathrm{ha}^{-1}$ \\
\hline Present & $186 \mathrm{a}$ & $89 \mathrm{a}$ & $112 \mathrm{a}$ & $28.05 \mathrm{a}$ & $5736 \mathrm{a}$ \\
\hline Absent & $173 \mathrm{~b}$ & $90 \mathrm{a}$ & $95 \mathrm{~b}$ & $28.43 \mathrm{a}$ & $5286 \mathrm{~b}$ \\
\hline Factor & \multicolumn{5}{|c|}{ ANOVA - F probability } \\
\hline Nitrogen application rate $(\mathrm{N})$ & $<0.001$ & 0.5383 & 0.0005 & 0.0125 & 0.0127 \\
\hline Rhizobacterium (R) & 0.0266 & 0.7453 & 0.0013 & 0.1829 & 0.0489 \\
\hline \multirow[t]{2}{*}{$\mathrm{N} \times \mathrm{R}$} & 0.0607 & 0.3038 & 0.6562 & 0.1718 & 0.4824 \\
\hline & & & $P$ & & \\
\hline Present & $178 \mathrm{a}$ & $82 \mathrm{a}$ & $94 \mathrm{a}$ & $28.35 \mathrm{a}$ & $5894 \mathrm{a}$ \\
\hline Absent & $166 \mathrm{~b}$ & $82 \mathrm{a}$ & $83 \mathrm{~b}$ & $29.29 \mathrm{a}$ & $5113 \mathrm{~b}$ \\
\hline Factor & \multicolumn{5}{|c|}{ ANOVA $-\mathrm{F}$ probability } \\
\hline Phosphorus application rate $(\mathrm{P})$ & 0.3325 & 0.3158 & 0.8096 & 0.1623 & 0.0743 \\
\hline Rhizobacterium (R) & 0.0352 & 0.9231 & 0.0142 & 0.0562 & 0.0002 \\
\hline \multirow[t]{2}{*}{$\mathrm{P} \times \mathrm{R}$} & 0.2090 & 0.1198 & 0.8840 & 0.9692 & 0.8622 \\
\hline & & & $\mathrm{K}$ & & \\
\hline Present & $179 \mathrm{a}$ & $86 \mathrm{a}$ & $99 \mathrm{a}$ & $28.31 \mathrm{a}$ & $5375 \mathrm{a}$ \\
\hline Absent & $163 \mathrm{~b}$ & $82 \mathrm{a}$ & $97 \mathrm{a}$ & $26.83 \mathrm{~b}$ & $4971 \mathrm{~b}$ \\
\hline Factor & \multicolumn{5}{|c|}{ ANOVA - F probability } \\
\hline Potassium application rate (K) & 0.2488 & 0.3729 & 0.0915 & 0.3450 & 0.2562 \\
\hline Rhizobacterium (R) & 0.0486 & 0.1265 & 0.6027 & 0.0016 & 0.0207 \\
\hline $\mathrm{K} \times \mathrm{R}$ & 0.0759 & 0.2336 & 0.3394 & 0.6877 & 0.9984 \\
\hline
\end{tabular}

*Values followed by the same letter in each column do not differ from each other according to a Tukey test at $\mathrm{p}<0.05$. Each mean is the average of 16 means (four replications and four N, P or K application rates). 
In the $\mathrm{K}$ trial, similar to the $\mathrm{P}$ trial, $\mathrm{GY}$ was the same regardless of the increases in K. However, there was a single effect of BRM 32110 on SDM, $1000 \mathrm{M}$ and GY. According to Sousa and Lobato (2004), the experimental soil had a high level of fertility, with high amounts of $\mathrm{P}$ and $\mathrm{K}$. Therefore, we can infer that in highly fertile soil, it is not necessary to apply $\mathrm{P}$ and $\mathrm{K}$ fertilizers and that the use of the rhizobacterium BRM 32110 can provide significant increases in flooded rice grain yield. Further, we can infer that the use of this microorganism can lead to saving money by reducing the fertilization of highly fertile soil.

These trials, performed in highly fertile soil and with four $\mathrm{N}, \mathrm{P}$ and $\mathrm{K}$ application rates, showed that these nutrients had no interactions with the rhizobacterium studied. In other words, rhizobacterium BRM 32110 supported increases in flooded rice development, which were confirmed in the gas exchange rate, nutrient content, yield components and grain yield of the plants, independent of the N, P and $\mathrm{K}$ application rates. This result is different from those of Shaharoona et al. (2008), Zahir et al. (2008) and Nascente et al. (2019b), who worked in aerobic conditions and treated wheat and rice plants with Pseudomonas sp.; these authors observed increases in development and grain yield in plants with different levels of fertilizers. However, their studies were not conducted in highly fertile soil or saturated soil. Our trial, performed in a tropical region with no water deficit and high levels of $\mathrm{P}$ and $\mathrm{K}$, showed that it is important to apply the correct amount of nutrients as defined by soil analyses and prior recommendations and that the use of rhizobacterium BRM 32110 (Bacillus thuringiensis) induced biomass increases, higher nutrient absorption, photosynthetic apparatus efficiency and rice yield. In addition to being ecologically friendly, this microorganism has the potential to sustainably increase tropical flooded rice production.

In addition, the use of BRM 32110 provided economic and environmental benefits due to the reduction in the use of chemical inputs and, consequently, the cost of production and pollution, respectively. Another important observation is that BRM 32110 is a biocontrol agent that can be used against Magnaporthe oryzae, the causal agent of rice blast (FILIPPI et al., 2011). Given all the beneficial effects of BRM 32110, we can characterize it as a multifunctional microorganism. The use of beneficial microorganisms in crop systems is increasing worldwide due to their reduced price in relation to that of synthetic inputs and the benefits they provide to the systems in which they are applied. Further, these microorganisms allow us to use biodiversity to improve plant development. The microorganism tested herein was selected from aerobic rice and was shown to be efficient in flooded rice. Next, we will develop a formulated product from this microorganism to make it available to farmers.

\section{CONCLUSION}

The use of rhizobacterium BRM 32110 led to increases in tropical flooded rice development, which could be observed in the gas exchange rate, nutrient content, yield components and grain yield of plants, independent of the $\mathrm{N}, \mathrm{P}$ and $\mathrm{K}$ rates applied under fertile soil conditions.

\section{ACKNOWLEDGEMENTS}

We thank Embrapa for supporting this research [grant number 22.13.06.027.00.00, 2017] and the National Council for Scientific and Technological Development (CNPq) for an award for excellence in research to the first and second authors.

\section{REFERENCES}

AHEMAD, M. S.; KIBRET, M. Mechanisms and applications of plant growth promoting rhizobacteria: current perspective. Journal of King Saud University, 26: 1-20, 2014.

ALVARES, C. A. et al. Köppen's climate classification map for Brazil. Meteorologische Zeitschrift, 22: 711-728, 2014.

BARIS, O. et al. Use of plant-growth-promoting rhizobacteria PGPR seed inoculation as alternative fertilizer inputs in wheat and barley production. Communications in Soil Science and Plant Analysis, 45: 2457-2467, 2014.

BULGARELLI, D. et al. Structure and functions of the bacterial microbiota of plants. Annual Review of Plant Biology, 64: 807-838, 2013.

DONAGEMA, G. K. et al. Manual of soil analyses methods, 2. ed. Rio de Janeiro, RJ: Embrapa Solos, 2011. $230 \mathrm{p}$

FAGERIA N. K. The Use of Nutrients in Crop Plants. Boca Raton, Florida: CRC Press. 2009. 448 p.

FAGERIA N K. Nitrogen management in crop production. Boca Raton, Florida: CRC Press, 2014. $436 \mathrm{p}$.

FEISTLER, A. M.; HABERMANN, G. Assessing the role of vertical leaves within the photosynthetic function of Styrax camporum under drought 
conditions. Photosynthetica, 50: 613-622, 2012.

FILIPPI, M. C. C. et al. Leaf blast Magnaporthe oryzae suppression and growth promotion by rhizobacteria on aerobic rice in Brazil. Biological Control, 58: 160-166, 2011.

FRANÇA, S. K. S. et al. Biocontrol of sheath blight by Trichoderma asperellum in tropical flooded rice. Agronomy for Sustainable Development, 35: 317 $324,2015$.

GLOBAL RICE SCIENCE PARTNERSHIP GRiSP. 2013. Rice almanac: Source book for one of the most important economic activities on Earth. Disponível em: <http://ageconsearch.umn.edu// handle/164484>. Acesso em: 20 set. 2019.

KADO C J, HESKETT M G. Selective media for isolation of Agrobacterium, Corynebacterium, Erwinia, Pseudomonas and Xanthomonas. Phytopathology, 60: 969-976, 1970.

KUAN, K. B. et al. Plant growth-promoting rhizobacteria inoculation to enhance vegetative growth, nitrogen fixation and nitrogen remobilisation of maize under greenhouse conditions. Plos One, 11: e0152478, 2016.

LADHA, J. K. et al. Efficiency of fertilizer nitrogen in cereal production: Retrospect and prospects. Advances in Agronomy, 87: 85-156, 2005.

LAVAKUSH, Y. J. et al. Evaluation of PGPR and different concentration of phosphorus level on plant growth, yield and nutrient uptake of rice Oryza sativa. Ecological Engineering, 62: 123-128, 2014.

MAKINO, A. Photosynthesis, grain yield, and nitrogen utilization in rice and wheat. Plant Physiology, 155: 125-129, 2011.

MANTELIN, S.; TOURAINE, B. Plant growthpromoting bacteria and nitrate availability: impacts on root development and nitrate uptake. Journal of Expimental Botany, 55: 27-34, 2004.

MARTINS, R. M. et al. Nitrous oxide and ammonia emissions from $\mathrm{N}$ fertilization of maize crop under no-till in a Cerrado soil. Soil and Tillage Research, 151: 75-81, 2015.

NASCENTE, A. S. et al. Biomass, gas exchange, and nutrient contents in upland rice plants affected by application forms of microorganism growth promoters. Environmental Science and Pollution Research, 24: 2956-2965, 2017a.

NASCENTE, A. S. et al. Effects of beneficial microorganisms on flooded rice development.
Environmental Science and Pollution Research, 24: 25233-25242, 2017b.

NASCENTE, A. S. et al. N Fertilizer DoseDependent Efficiency of Serratia spp. for Improving Growth and Yield of Upland Rice Oryza sativa L. International Journal of Plant Production, 13: 217-226, 2019a.

NASCENTE, A. S. et al. Upland rice gas exchange, nutrient uptake and grain yield as affected by potassium fertilization and inoculation of the diazotrophic bacteria Serratia spp. Australian Journal of Crop Science, 6: 944-953, 2019b.

OLANREWAJU, O. S.; GLICK, B. R.; BABALOLA, O. O. Mechanisms of action of plant growth promoting bacteria. World Journal of Microbiology and Biotechnology, 33: 197, 2017.

ONO, K. et al. Canopy-scale relationships between stomatal conductance and photosynthesis in irrigated rice. Global Change Biology, 19: 2209-2220, 2013.

PÉREZ-GARCÍA, A.; ROMERO, D.; VICENTE, A. Plant protection and growth stimulation by microorganisms: biotechnological applications of Bacilli in agriculture. Current Opinion in Biotechnology, 22: 187-193, 2011.

RÊGO, M. C. F. et al. Morphoanatomical and Biochemical Changes in the Roots of Rice Plants Induced by Plant Growth-Promoting Microorganisms. Journal of Botany, 2014: 1-10, 2014.

SHAHAROONA, B. et al. Fertilizer-dependent efficiency of Pseudomonads for improving growth, yield, and nutrient use efficiency of wheat Triticum aestivum L. Applied Microbiology and Biotechnology, 79: 147-155, 2008.

SILVA, J. C. et al. Rice sheath blight biocontrol and growth promotion by Trichoderma isolates from the Amazon. Revista de Ciências Agrarias, 55: 243 250,2012

SOUSA, D. M. G.; LOBATO, E. Cerrado: soil correction and fertilization, 2. ed., Brasília, DF: Embrapa Cerrados, 2004. 416 p.

SOUSA, I. M.; NASCENTE, A. S.; FILIPPI, M. C. C. Growth promoting bacteria on root length of seedlings of two flooded flooded rice cultivars. Colloquium Agrariae, 15: 140-145, 2019.

SPERANDIO, E. M. et al. Evaluation of rhizobacteria in upland rice in Brazil: growth promotion and interaction of induced defense 
responses against leaf blast Magnaporthe oryzae. Acta Physiologiae Plantarum, 39: 259, 2017.

ZAHIR, Z. A. et al. Effectiveness of rhizobacteria containing ACC-deaminase for growth promotion of pea Pisum sativum under drought conditions. Journal of Microbiology and Biotechnology, 18: 958-963, 2008.

ZHANG, G, et al. Effects of physic-chemical parameters on the bacterial and fungal communities during agricultural waste composting. Bioresource Technology, 102: p. 2950-2956, 2011. 